DOI: 10.46340/ephd.2020.6.4.11

Vitaliya Gotynyan-Zhuravlyova, PhD in Philosophy

ORCID ID: https://orcid.org/0000-0003-0830-3893

Odessa I. I. Mechnikov National University, Ukraine

\title{
ABOUT THE POSSIBILITY OF A STANDARDLESS MEASUREMENT OF VALUE ORIENTATIONS OF THE PERSONALITY
}

\author{
Віталія Готинян-Журавльова, к. філос. н. \\ Одеський національний університет імені І.І. Мечникова, Україна \\ ПРО МОЖЛИВІСТЬ БЕЗЕТАЛОННОГО \\ ВИМІРЮВАННЯ ЦІННІСНИХ ОРІЕНТАЦІЙ \\ ОСОБИСТОСТІ
}

The modern pace of life requires a person to reconsider his/her needs, motives, purposes, ways of the achieving purpose. At the same time there is a change of the personality under the influence of external changes. The personality can be seen as a system of the values. These values become the main guide in the selection of the purpose and motivation to action. The value orientation is formed under the influence of value. Therefore, the definition (or the measurement) requires the change of the value orientations of the individual. The question arises about how to measure the value orientations. Let us turn to the standardless measurement. The standardless measurement is measurement that occurs without the use of a standard of the measured value. With its help it is possible to measure and describe process of formation of the value orientation, to qualitatively characterize, to estimate the value orientation, its influence on a moral estimation of events and the phenomena.

Keywords: values, value orientation, moral evaluation, personality, change, standardless measurement.

Вступ. Ми часто чуємо і використовуємо вислів: «Все має свою ціну. Все можна оцінити». А чи можна оцінити людське життя? Яку воно має ціну? Особливо гостро це питання постало в період пандемії COVID-19. Ще гостріше цінність людського життя відчувалася, коли італійські лікарі стояли перед вибором: кому з пацієнтів раніше надавати допомогу. Може тому нам складно уявити, що ще кілька століть тому на турецькому базарі людину можна було купити за жменю тютюну. Але які ціннісні орієнтації повинні бути у людини, яка має оцінювати, визначати, виміряти людські якості, компетенції, людську поведінку? За останні роки наше суспільство перетерпіло цілу низку змін, зокрема, змін політичних, соціальних, економічних, що безумовно привело до зміни усталеної системи цінностей, притаманних нашому суспільству, і заміни деяких з них на нові, які відповідають потребам життя. Виникає питання: як визначити, вимірити швидкість цих змін? Як визначити міру впливу суспільних змін на зміну ціннісних орієнтацій людини?

Найчастіше цінність розуміють як поняття про значущість для людини того чи іншого явища або події. За допомогою цінностей і ціннісних орієнтації людина виокремлює значуще, істотне, важливе для неї від незначущого, неістотного та неважливого. Сучасний темп життя вимагає від людини перегляду iii потреб, мотивів, цілей, які вона перед собою ставить, способів досягнення мети. При цьому під впливом зовнішніх змін відбувається зміна самої особистості, яка може бути представлена як система цінностей, які стають головним орієнтиром у виборі мети, та спонукають до дій. Ця система цінностей складається відповідно до оточуючої дійсності, з іншого боку, - залежить «від соціальної сутності людини та іії залежності від духовно-моральних, економічних і політичних суспільних відносин, а 3 третього - від зв'язку людини з над особистісними, загальносвітовими, вищими духовними цінностями, що існують трансцедентально ${ }^{1}$. Так в XXI столітті, особливо зараз, під час пандемії

\footnotetext{
${ }^{1}$ Александрова, О. (2012). Роль і місце ціннісних орієнтацій у сучасній теорії виховання. Вісник Запорізького національного університету, 1(17), 93.
} 
COVID-19, знов на перший план виходять такі цінності, як життя, здоров'я, родина, дещо зменшуючи цінність грошей, успіху, бізнесу. Під впливом цінностей формуються нові ціннісні орієнтації. Тому цінності і ціннісні орієнтації людини, по суті, є соціально-психологічним показником змін, які відбуваються у суспільстві. Навіть в утворені професійно важливих якостей особистості беруть участь не лише сукупність професійних властивостей особистості, а й їі особистісні якості людини, які $€$ важливими для її професійної діяльності.

Отже, визначення, а точніше вимірювання, потребують як суспільні зміни, так і зміні ціннісних орієнтацій особистості. Виникає питання щодо способу вимірювання ціннісних орієнтацій. На перший погляд, видається що слід застосувати надійніший метод еталонного вимірювання. Але використання цього методу щодо вимірювань в соціальній та психологічній, суспільних галузях пов'язано з цілою низкою труднощів, перш за все, це пошук еталонів вимірюваних величин. На нашу думку, в такій ситуації слід звернутися до альтернативного безеталонного вимірювання. Серед авторів, які активно розробляли питання про способи і використання альтернативних видів вимірювання слід зазначити К. Берку, Н. Ф. Єфімову, В. І. Звоннікова, С. І. Алексєєву, М. А. Ступицьку, Н. С. Прокопенка, О. С. Середу, М. Бучіна, В. О. Ядова, М. В. Степанова, Ю. М. Толстову, О. В. Попову, І. Д. Ковальченка. Про необхідність, методологію, особливості застосування, безеталонного вимірювання йшлося в роботах академіка А. І. Уйомова, Г. А. Полікарпова, О. М. Єфімова, В. М. Кутєєва, В. П. Малайчука, А. В. Мозгового, О. П. Пунченка.

Метою даної статті є аналіз процесу формування ціннісних орієнтацій, аналіз самих ціннісних орієнтацій і можливість їх вимірювання за допомогою безеталонного вимірювання.

Що таке ціннісні орієнтації, і як саме вони формуються? В європейській філософії проблема цінностей сформульовані в етиці І. Канта, центральним поняттям якої є імперативи і максими. Пригадаємо два формулювання категоричного імперативу: завжди потрібно ставитися до людини i до самого себе як до мети, а не лише як до засобу; завжди треба поводитись так, щоб максима вчинку могла б стати загальним законом для всіх. Кантівський імператив визначає своєрідний еталон відношення до людини і оцінки певних подій відповідно до людини й до людського життя. Але як зазначають Д. М. Кислинська i Н. Е. Мілорадова «для більшості теорій, які можна віднести до «біологічного» або «природнонаукового» класу психології, цінності не $\epsilon$ емпіричноверифікованими категоріями» ${ }^{1}$. Найбільш яскраво це визначено в теорії К. Левіна, який свідомо виключає ціннісні судження з системи наукових понять. Головною перевагою емпіричного способу мислення, на його думку, $\epsilon$ те, що «в ньому не простежується «ніяких ціннісних концепцій»»» ${ }^{2}$. Будь-яке наукове знання, будь-яка наукова теорія не можуть бути ані добрими, ані злими, ані гарними, ані поганими з моральної точки зору. Протягом довгого часу вважалося, що усе наукове знання - морально нейтральне. Так, дійсно, добрим чи поганим $є$ знання про те як відбувається розчеплення ядра урану, при якому вивільняється певна кількість енергії? Науковці вважають це знання морально нейтральним. Зовсім інше - це як розпорядитися цим знанням, що створити на основі цих знань: «мирний атом» (атомні електростанції, атомні двигуни), який допоможе заощадити природні ресурси, або зброю масової поразки?

Це питання загострилося протягом Другої Світової війни. Про ціннісну окраску наукового знання йшлося на Нюрнберггському процесі, де окремо розглядалася «справа лікарів». 3 одного боку, величезна кількість експериментів, які проводилися на людях, надала дослідникам цінну інформацію в певних галузях медицини і обумовило їх подальший розвиток, а з іншого боку, не можна забути, яким чином була отримана ця інформація. Виявилася, що на одній чаші терезів стоїть жага відкриття, виявлення нових наукових горизонтів, створення ліків чи отримання інформації, які в подальшому можливо збережуть багато людських життів, а на іншій чаші - людські життя, які без згоди, без доброї волі були забрані задля цих експериментів.

Отже, наука не може залишатися морально нейтральною, коли мова йде про людське життя, i тут вже неможна обійтися без ціннісної оцінки мети, способів, якими було проведено дослідження, i використання отриманих результатів. Хочеться пригадати слова відомого психолога Б. Ф. Скіннера: «ціннісні судження лише там виходять на вірний слід, де цей слід залишила наука. А коли ми навчимося планувати і вимірювати дрібні соціальні взаємодії та інші явища культури з такою ж точністю, якою ми володіємо у фізичній технології, то питання про цінність відпаде сам собою» ${ }^{3}$.

\footnotetext{
${ }^{1}$ Кислинська, Д., Мілорадова, Н. (2016). Цінності та ціннісні орієнтації в психологічних теоріях. Вісник ХНПУ імені Г. С. Сковороди. Психологія, 53, 64.

${ }^{2}$ Там само, 65.

${ }^{3}$ Там само.
} 
Якщо науковці почнуть не лише надавати оцінку, а й об'єктивно вимірювати соціальні, політичні, економічні явища і події, надавати максимально об'єктивний аналіз отриманим результатам, уникаючи аналізу крізь призму ціннісних орієнтацій, то наука знову зробить крок до моральної нейтральності знання. Але кількісно (еталонно) і об’єктивно вимірити швидкість розповсюдження важливої інформації, саму цінність отриманої інформації, реакцію суспільства на неї без урахування ціннісних орієнтацій неможливо. А тому неможна «очистити» науку від суб'єктивного, від цінностей, від якісної оцінки явищ, подій, отриманих результатів.

Як ціннісні орієнтації часто розуміють життєві ідеали, прагнення, бажання, цілі, установки на ті чи інші цінності матеріальної або духовної культури суспільства. Ціннісні орієнтації є своєрідним відображенням у свідомості особистості цінностей, які визнаються нею як цілі та орієнтири, що сформувалися завдяки співвіднесення особистісного досвіду 3 еталонними (або скоріше квазіеталонними) зразками культури. На думку Р. С. Чіп, ціннісні оріснтації розглядаються як «суб'єктивний образ культурних цінностей, тобто специфічно засвоєну цінність у відповідності до індивідуального досвіду особистості» ${ }^{1}$. Суспільство формує певну систему цінностей, які пізнає особистість, зокрема і в процесі спілкування. Ціннісні орієнтації виробляються не в кожного індивіда, а лише в такого, який дійшов до необхідного ступеню розвитку. Перехід до ціннісних орієнтацій відбувається шляхом поступового їх закріплення у відповідних ситуаціях, які відповідають тому чи іншому рівню потреб. Наявність усталених ціннісних орієнтацій свідчить про зрілість людини. У ціннісних орієнтаціях акумулюється життєвий досвід людей. Так, ціннісні орієнтації часто розуміють як відображення у свідомості людини цінностей, які обрані нею як стратегічні життєві цілі, як світоглядні орієнтири.

Отже, аналіз ціннісних орієнтацій, моральних критеріїв, вчинків, поведінки людини повинен містити в собі елемент оцінки, а для надання оцінки часто необхідним стає проведення вимірювання. Сучасну науку неможливо уявити без процедури вимірювання. Вимірювання існує як самостійний емпіричний метод дослідження і як частина іншого емпіричного методу пізнання - експерименту, якій все частіше вживається і в суспільно-гуманітарних науках. Вимірити все, що можна, i перетворити на вимірні ті величини, які до цього неможна було вимірити - по суті стає девізом сучасної науки. Але як бути з вимірюванням і оцінюванням ціннісних орієнтацій, які сформувалися у людини? Які методи, способи і «еталони» можна при цьому застосовувати?

Перше, що ми повинні усвідомити при обговорені способів оцінки ціннісних орієнтацій, що про використання жодних еталонів взагалі не йдеться. Часто «еталоном» моральних вчинків людини називають відомий категоричний імператив I. Канта. При поверхневому аналізі може скластися враження, що таким еталоном є людина, яка може бути лише метою, а не засобом. Але ж еталон - це чітко фіксована міжнародна величина, це засіб вимірювання, одним з завдань якого $є$ також збереження і відтворення одиниці фізичної величини задля подальшої передачі їі розміру іншим засобам вимірювання, які розташовані нижче в перевірочній схемі засобів вимірювання. Тому, якщо в повсякденному житті ми часто вживаємо цей термін поряд з зовсім нефізичними величинами («еталон краси», «еталон чесності», «зразкові (еталонні) манери», тощо), то застосування цього терміну до моральних понять йде в супереч його значенню. На нашу думку, при аналізі подібних величин доцільніше використовувати поняття «квазіеталон», який не $\epsilon$ міжнародним зафіксованим стандартом даної величини.

Якщо продовжимо аналіз категоричного імперативу I. Канта, то там, де йдеться про вимогу того, щоб максима вчинку могла стати загальним для всіх законом, те ж, на перший погляд, йдеться про еталон і єдиний загальний для більшості механізм вимірювання. Але, знов-таки, на перший погляд, адже навіть неможливо уявити ситуацію, за якій будуть створені еталони для вимірювання моральних, етичних понять, ціннісних орієнтацій і єдиний механізм вимірювання, на зразок еталонного вимірювання.

Іншим блискучим прикладом зразка (еталона) моральної поведінки людини є Десять заповідей Божих, десять основних законів, які були надані Мойсею Богом на горі Синай на п'ятдесятий день після Ісходу із Сгипту. Вони без сумніву $є$ законом і зразком для поведінки будь-якого віруючого православного, католика, іудея. Шоста заповідь: не убий. Ми знаємо, що особливо сумлінно Закону Божого дотримуються монахи і священики. Але історія православної церкви знає чимало прикладів, коли священики порушували цю заповідь і брали до рук зброю. Це можливо було за єдиної умови: захищати від ворога свою Батьківщину.

\footnotetext{
${ }^{1}$ Чіп, Р. (2012). Ціннісні орієнтації як механізми регуляції поведінки особистості. Проблеми сучасної психології, $18,818$.
} 
Знов-таки складно визначити Заповіді як еталони, враховуючи значення терміну «еталон». Отже, на нашу думку, слід звернутися до безеталонного вимірювання. Про безеталонне вимірювання моральних, етичних понять і категорій йдеться в роботах О. П. Пунченка: «безеталонне вимірювання може розглядатися як загальновизначений людством інтервал, в рамках якого позитивно функціонує зміст даного морального поняття або категорії. Моральні категорії, і структурні, такі як норма, принцип, оцінка, ідеал, погляди, знання... не можуть мати єдиного кількісного еталону, оскільки вони функціонують як міра» ${ }^{.}$. Дійсно, складно навіть уявити, як можна, застосовуючи еталони, виміряти мотиви, цілі, мету, вплив емоцій, традицій, виховання, моралі, настрою на прийняття того чи іншого рішення, оцінку тієї чи іншої події, навіть просто на концентрацію уваги, зосередженості при виконання вимірювання, обробці результатів, особливо якщо йдеться про царину суспільногуманітарних наук. А як позбутися впливу всього цього «суб'єктивного», позбутися якого вимагає від нас еталонне вимірювання?

Звернімося до безеталонного вимірювання і за його допомогою спробуємо надати оцінку тим чи іншим явищам, подіям, моральним вчинкам, а також якісно описати процес формування ціннісних орієнтацій особистості. Безеталонне вимірювання - це вид вимірювання, яке відбувається без використання обов'язкового еталону вимірюваної величини, натомість відбувається класифікація об'єкту, що вимірюються, за наявністю або відсутністю вимірюваної ознаки, порівняння вимірюваної ознаки з квазіеталоном вимірюваної величини та за комбінацією ознак, за допомогою яких вимірюється, а інколи і утворюється досліджувана річ².

Пригадаємо, що коли людина пізнає предмети, явища оточуючого іï світу, то одразу визначає їхню значущість для себе i, в першу чергу, їх цінність або не цінність для себе. Це складний процес, який спочатку грунтується на емоційних враженнях і переживаннях, які потім раціонально усвідомлюються і набувають форму мети. Часто ціннісні оріснтації розуміють як результат проекції цінностей, які ми визначили для себе як значущі, на площину індивідуальної свідомості. Описати і оцінити цей процес можна за допомогою виду безеталонного вимірювання, який засновано на зіставлені ознаки з вимірюваним об'єктом, в процесі якого ми визначаємо чи належить ознака вимірюваній речі, чи не належить. Позначається даний вид безеталонного вимірювання як $\mathrm{R}(\mathrm{P}, \mathrm{m})$. В нашому випадку відбувається прийняття або не прийняття певних цінностей. Яскраво $і$ безпосередньо демонструють цей процес діти, коли цікавляться (роздивляються, гризуть, ламають) певну річ або не цікавляться нею, майже одразу відкидають.

Цінність завжди об'єктивна. Існують загальнолюдські, національні, колективні, індивідуальні цінності. Найвищі цінності не залежать від історичних умов, соціальних змін, поглядів окремих людей. Ціннісні орієнтації завжди суб'єктивні. На думку О. Ф Александрової, багато дослідників трактують ціннісні орієнтації як «установку особистості на ті або інші цінності матеріальної і духовної культури суспільства. Вони вважають, що ціннісні орієнтації являють собою найважливіший компонент структури особистості, який визначає іiі поведінку i ставлення до навколишнього світу» ${ }^{3}$. Формуються ціннісні орієнтації на основі комбінації значущих для особистості цінностей, які відбиваються в їі свідомості. Той самий автор наводить інше визначення ціннісних орієнтацій, а саме, «це порівняно стійкі відношення людини та сукупності матеріальних, соціальних, духовних благ, ідеалів, що виступають як предмети, цілі та засоби для задоволення потреб життєдіяльності людини» ${ }^{4}$. На нашу думку, процес формування ціннісних орієнтацій описує вид безеталонного вимірювання, який засновано на комбінації ознак, які утворюють, визначають, вимірюють річ. Позначається даний вид безеталонного вимірювання як $\mathrm{R}\left(\mathrm{P}_{1}, \mathrm{P}_{2}, \ldots \mathrm{P}_{\text {п }}\right)$.

Більшість дій та вчинків людини потребує оцінки. Цілі, які ставить перед собою людина, також потребують оцінки. Саме завдяки наданню оцінки тим чи іншим явищам і подіям людина пов'язує себе не лише з навколишньою природою i соціальною дійсністю, а й 3 іншими людьми, з суспільством в цілому. Саме завдяки оцінці відбувається поєднання почуття і логіки.

Ціннісні орієнтації, які сформувалися у людини, часто виступають підгрунтям для морального оцінювання - схвалення або осудження діяльності людини з позиції тих вимог, тих життєвих орієнтирів, які містяться в моральній свідомості суспільства, етнічній групи, соціальної спільноти

\footnotetext{
${ }^{1}$ Пунченко, О. (2008). Безеталонне вимірювання духовності. Актуальні проблеми духовності. Збірник наукових праць, 2 (18), 364.

${ }^{2}$ Готинян, В. (2005). Логіко-системні аспекти проблеми вимірювання. Одеса: ОНУ.

${ }^{3}$ Александрова, О. (2012). Роль і місце ціннісних орієнтацій у сучасній теорії виховання. Вісник Запорізького національного університету, 1 (17), 93-98.

${ }^{4}$ Там само.
} 
людей, тих чи інших особистостей. Суб'єктивність будь-якого морального оцінювання обумовлена, в першу чергу, системою цінностей, які сформувалися у суб'єкта оцінювання, його потребами та інтересами. На нашу думку, така система морального оцінювання відповідає виду безеталонного вимірювання, який засновано на порівнянні ознаки (або системи ознак), які взяті в якості певного квазіеталону для вимірювання, з ознакою, яка належить об'єкту вимірювання. Цей вид безеталонного вимірювання позначається як $\mathrm{R}\left[\mathrm{P}_{1},\left(\mathrm{~m}_{*}\right) \mathrm{P}_{2}\right]$. В нашому випадку схвалення або осудження певної дії, певного поступку людини $\left(\left(\mathrm{m}_{*}\right) \mathrm{P}_{2}\right)$ відбувається на основі порівняння 3 певними вимогами, внутрішніми критеріями, ціннісними орієнтаціями людини $\left(\mathrm{P}_{1}\right)$, яка здійснює це оцінювання.

Цікавою виявляється процедура моральної оцінки у правозастосуванні. Найчастіше критерієм або підставою для морального оцінювання вчені називають певну ціннісну орієнтацію, грунтуючись на якій, суб'єкт здійснює оцінювання. Крім того, у випадку морального оцінювання у правозастосуванні правознавці використовують поняття еталону оцінювання. Еталон морального оцінювання у правозастосуванні - це «нормативна модель певного виду об'єктів правозастосовного оцінювання, сформована на основі уявлень про належне, які існують в індивідуальній та / або суспільній свідомості» ${ }^{1}$. Отже, ми маємо критерій морального оцінювання та еталон морального оцінювання, між якими існує певний функціональний зв' язок, оскільки завдяки критерію оцінювання обирається еталон. Крім того, в процесі морального оцінювання виокремлюються певні причини вибору саме такого оціночного еталону та порівняння з цим еталоном конкретного об'єкта, що в решті-решт формує моральну оцінку. До них можна віднести культурні, етичні, моральні чинники, а також індивідуальні потреби і інтереси того, хто оцінює, його моральну та правову свідомість.

Але, на нашу думку, йдеться скоріше про квазеталон, ніж про еталон у стандартному значенні цього терміну. Так еталон $є$ усталеним міжнародним загально визначеним стандартом певної величини. В наведеному вище визначенні йдеться про те, що еталон по суті формується на основі уявлень про належне, які існують в індивідуальній або суспільній свідомості. Тобто, на нашу думку, таке трактування еталону не відповідає жорсткому критерію об'єктивності, яке є головною умовою для обрання еталону певної величини. Крім того, найчастіше до умов вибору еталону належать «різноманітні матеріальні умови, в яких здійснюється правозастосовна діяльність - стан економіки, рівень фактичної завантаженості правозастосовця - ступінь його незалежності тощо» ${ }^{2}$. А тому при моральному оцінюванні у правозастосуванні краще використовувати поняття «квазіеталон», яке не обмежено такими жорсткими вимогами як поняття «еталон», про що йшлося раніше. В цьому випадку для опису механізму морального оцінювання можна застосувати вид безеталонного вимірювання, який засновано на порівнянні двох речей, одна з яких обрана як квазіеталон, а інша $€$ вимірюваною річчю. Цей вид безеталонного вимірювання позначається як $\mathrm{R}\left(\mathrm{m}_{1}, \mathrm{~m}_{2}\right)$. В результаті такого вимірювання можна (за потребою) отримати число, яке буде вказувати на те, у скільки разів вимірюваний об’єкт більше, менше, твердіше, м'якіше, добріше, розумніше, моральніший, освіченіший і т.п. за об'єкт, який обрано в якості квазіеталону для порівняння.

Отже, якщо йдеться про оцінку або якісне вимірювання тих чи інших поступків людини, іiі поведінки за певних обставин, якості знань, особистісних критеріїв, визначення певної системи цінностей, яка склалася в людини під впливом суспільства, його традицій, заборон, норм поведінки, суспільно значущих подій тощо, слід звертатися до безеталонного вимірювання. Саме за допомогою безеталонного вимірювання можна виміряти і описати процес формування ціннісних орієнтацій, якісно охарактеризувати, в більшості випадків оцінити самі ціннісні орієнтації, і не тільки самі ціннісні орієнтації, але й їх вплив на моральну оцінку подій і явищ. Оскільки зміни у сучасному суспільстві відбуваються занадто швидко, то виявляється цікавим не лише визначити швидкість цих змін, їх якісну характеристику, а оскільки усі ці зміни відбиваються на системі ціннісних орієнтаціях людини, і вони теж повинні змінюватися, то питання щодо застосування безеталонного вимірювання стосовно визначення цих змін $є$ доволі актуальною проблемою сучасної філософії і методології науки. Уточнення (i, можливо, подальша формалізація) самих механізмів безеталонного вимірювання, можливість застосування видів безеталонного вимірювання при вимірюванні конкретних ціннісних орієнтацій, вибір найбільш точного і відповідного виду безеталонного вимірювання складають перспективу подальшого дослідження цього питання.

\footnotetext{
${ }^{1}$ Тарнавська, М. І. (2011). Критерій морального оцінювання у правозастосуванні: структурно-функціональний аналіз.Держава і право. Наукова електронна бібліотека періодичних видань НАН України <http://dspace.nbuv.gov.ua/bitstream/handle/123456789/32815/12-tarnavska.pdf?sequence=1> (2020, листопад, 12). ${ }^{2}$ Там само.
} 


\section{References:}

1. Aleksandrova, O. (2012). Rol i mistse tsinnisnykh oriientatsii u suchasnii teorii vykhovannia [The role and place of value orientations in modern theory of education]. Visnyk Zaporizkoho natsionalnoho universytetu [The Bulletin of Zaporizhia National University], 1 (17), 93-98. [in Ukrainian].

2. Kyslynska, D., Miloradova, N. (2016). Tsinnosti ta tsinnisni oriientatsii v psykholohichnykh teoriiakh [The values and value orientations in psychological theories]. Visnyk KhNPU imeni H. S. Skovorody. Psykholohiia [Bulletin of KhNPU named after GS Skovoroda. Psychology], 53, 64-73. [in Ukrainian].

3. Chip, R. (2012). Tsinnisni oriientatsii yak mekhanizmy rehuliatsii povedinky osobystosti [The value orientations as mechanisms of regulation of personality behavior]. Problemy suchasnoi psykholohii [Problems of modern psychology], 18, 810-818. [in Ukrainian].

4. Punchenko, O. (2008). Bezetalonne vymiriuvannia dukhovnosti [The standardless measurement of spirituality]. Aktualni problemy dukhovnosti. Zbirnyk naukovykh prats [The current issues of spirituality. Collection of scientific works], 2 (18), 361-365. [in Ukrainian].

5. Gotynyan, V. (2005). Lohiko-systemni aspekty problemy vymiriuvannia [The logical and systems aspects of the problem of measurement]. Odesa: ONU. [in Ukrainian].

6. Tarnavska, M. I. (2011). Kryterii moralnoho otsiniuvannia u pravozastosuvanni: strukturno-funktsionalnyi analiz [The criterion of the moral evaluation in law enforcement: structural and functional analysis]. Derzhava i pravo [The state and the law]. Naukova elektronna biblioteka periodychnykh vydan NAN Ukrayiny [Scientific electronic library of periodicals of the National Academy of Sciences of Ukraine] <http://dspace.nbuv.gov.ua/bitstream/handle/123456789/32815/12-tarnavska.pdf?sequence=1>. (2020, November, 12). [in Ukrainian]. 